\title{
Assessing Brand Equity Through Add-on Sales
}

\author{
Donald R. Lehmann • Shuba Srinivasan
}

Published online: 18 December 2013

(C) Springer Science+Business Media New York 2013

\begin{abstract}
This paper focuses on add-on sales to determine both their value per se and their value as a reflexive measure of brand equity. Specifically, this paper examines the "accessory premium" for automobiles, i.e., accessories installed by dealers at the time of sale. Using J.D. Power Data, the authors find that higher add-on accessory sales accrue to higher equity brands which make accessory sales a potentially useful measure of brand equity (J. Marketing 67: 1-17, 2003). In addition, the authors examine how the revenue premium metric varies by age cohort. The results suggest this analysis can provide a useful predictor of future sales.
\end{abstract}

Keywords Brand equity $\cdot$ Revenue premium $\cdot$ Age cohort analysis $\cdot$ Leading indicator

\section{Introduction}

Brands are one of the key assets of a firm [22]. Strong brands facilitate extensions, particularly if they are consistent with the core properties of the home brand. Consequently, measuring the value of brands is an important activity. In particular, recent work has suggested that the revenue premium a brand commands versus a generic or private label equivalent is a useful measure of the brand equity of consumable products such as Coke and Tide [8].

D. R. Lehmann

Columbia Business School, Columbia University, 3022 Broadway,

Uris Hall, New York, NY 1002-6902, USA

e-mail: dr12@columbia.edu

S. Srinivasan $(\bowtie)$

Boston University School of Management, 595 Commonwealth

Avenue, Boston, MA 02215, USA

e-mail: ssrini@bu.edu
For durable goods, the revenue premium measure, though conceptually sound, can be difficult to assess. For one thing, there are not always generic or branded equivalent products (one exception was the Chevy Nova and Toyota Corolla built on the same assembly line). Revenue streams from after-markets, e.g., cartridges for printers, are not captured in the basic measure. Here, the focus is on the additional items and accessories/add-ons sold along with the base product. Accessories for a product are complements which are consumed with the base product. These add-ons can generate substantial revenue and, more importantly, profit margin. As an example, Jibbitz, a start-up firm selling accessories for the popular Crocs shoes, enjoyed such healthy profits that it was acquired by Crocs in 2006 for more than $\$ 10$ million within a year of its establishment [14]. In general, loaded cars, computers, etc. are very profitable, whereas the base models frequently are not.

This paper focuses on add-on sales to determine both their value per se and their value as a reflexive measure of brand equity. Specifically, this paper examines the "accessory premium" for automobiles, i.e., accessories installed by dealers at the time of sale. ${ }^{1}$ Using J.D. Power Data, we assess the size of the accessory sales for various automobile brands in the sedan category. We then examine the relationship between accessory sales and the brand revenue premium measure of Ailawadi, Lehmann, and Neslin [8], finding a high correlation between them. This paper therefore extends the brand revenue premium concept by introducing the notion of an accessory/add-on premium. We also examine how the revenue premium metrics vary by age cohort. The results suggest that accessory spending can be a useful predictor of future sales.

\footnotetext{
${ }^{1}$ We use the term 'accessory premium' and 'accessory sales' interchangeably to denote the proposed brand equity metric in the rest of the paper.
} 


\section{Background}

Brand equity is a widely studied topic (e.g., $[16,23])$, which has been examined at the consumer, product-market, and financial market levels. The benefits of brand equity are multiple and varied [20]. Brand equity increases the number of potential customers who have the brand in their consideration sets. It also increases the effectiveness of advertising and promotions. Importantly, it reduces sensitivity to price increases and to product failures [5] and increases sensitivity to price cuts. Furthermore, due to its impact on sales, it helps obtain distribution coverage and support. For example, research suggests that stores are more likely to feature familiar brands that convey a high-quality image [20,25].

Another important aspect of brand equity is its ability to facilitate brand extensions [4, 34]. Here, as in most work on brand equity, the focus of research has been on a single definable product (e.g., a cola). Yet one other important possible aspect of brand equity is its facilitation of up-selling and cross-selling additional items (accessories). Cross-selling, attempting to sell additional related products to current customers, involves selling both at the time of the initial sales as well as in the future. A commonly held view is that a brand's equity is reflected in the marketplace in terms of differential consumer purchases for the brand (e.g., [20]). The logic behind the analysis in this paper is quite simple. With respect to consumer durables, the more one values something, the more they want to protect and enhance it, and the longer they are likely to keep it. The latter makes adding accessories to the base product easier to justify on a cost per use basis for durables. Here, we focus on additional sales at the time of initial purchase (e.g., undercoating, rust-proofing, extended warranty, etc. for cars). In essence, this represents customer expansion at the time of sale. Furthermore, associated merchandise is a big part of movie revenue and a significant component in many sports team franchises. Indeed, a major element of brand equity can be the additional sales of optional accessories it generates in addition to the base item. In a sense, our emphasis here is in on an "optional" extended product, i.e., additional features that may be purchased along with it.

In terms of theoretical support for why consumers react differentially with regard to accessory purchases of brands with differences in brand equity, we draw upon prior research [20] for evidence on both direct and indirect mechanisms that might be at play. An example of the direct mechanism is loss aversion [15], where the possibility of a potential downside loss in purchasing optional add-on sales leads to an advantage for higher equity brands. In addition, consumers may rely on the affect associated with a familiar brand to aid in their decision making with regard to optional purchases. Indirect mechanisms are evoked when there is uncertainty or ambiguity in the decision environment which is often the case with "optional" purchases with the ambiguity favoring the stronger brand [32]. We next delineate how the proposed brand equity metric fits within the current brand equity metrics that have proposed in the branding literature and practice.

\section{Metrics of Brand Equity}

Brand equity's components vary in terms of whether the perspective of the consumer, product-market, or financial market is adopted [23]. From the customers' perspective, brand equity reflects how customers perceive and react differentially to a branded versus an unbranded offering. From the product-market perspective, brand equity is the enhanced performance in terms of sales and revenue of a branded offering compared to an equivalent unbranded one. From the financial market perspective, brand equity represents the value of an asset that can be traded and can be thought of as the net present value of anticipated future purchases of the brand. Table 1 provides an overview of the metrics, their definitions, and illustrative data sources and references for these metrics.

Customer-based brand equity, defined as "the differential effect of brand knowledge on consumer response to the marketing of the brand" [21], is the most commonly used equity definition among both researchers and practitioners [6]. The differential consumer response to the brand has been operationalized by a range of different metrics including EquiTrend's perceived quality measure, as well as Millward Brown's BrandZ indicator, and Ipsos' Equity*Builder, which both measure the consumers' emotional attachment to a brand. Young \& Rubicam's Brand Asset Valuator model proposes two dimensions of brand equity, each with two subcomponents as follows: brand strength includes brand differentiation and the relevance of the brand to the consumer, whereas brand stature considers the brand's esteem and consumer's knowledge (awareness and understanding) of the brand [7]. A recent addition is brand energy which captures the degree to which a brand is perceived as innovative and dynamic [30].

A commonly held view is that the value of the brand "must ultimately be derived in the marketplace" ([20], p. 421), i.e., result in market-based brand equity. Traditional metrics that reflect marketplace performance of the brand include price premium, revenue premium, increased advertising elasticity, and the ability to obtain distribution channel and shelf space, in addition to traditional market performance measures such as sales, profit, and market share $[8,12]$. The revenue premium metric proposed by Ailawadi et al. [8] is the difference in revenue (i.e., price $\times$ volume) for a branded good versus a private label good. The metric we propose in this paper, the brand accessory revenues measured as brand's unit volume $x$ (brand's price with after-market accessories-brand's price with factory installed options), is consistent with the view that the value of the brand is reflected in the marketplace. 
Table 1 Brand equity metrics

\begin{tabular}{|c|c|c|c|}
\hline $\begin{array}{l}\text { A. Customer-based } \\
\text { brand equity } \\
\text { Brand strength }\end{array}$ & $\begin{array}{l}\text { Sample data } \\
\text { sources }\end{array}$ & Illustrative papers & Definition \\
\hline $\begin{array}{l}\text { Brand differentiation } \\
\text { Brand relevance } \\
\text { Brand energy }\end{array}$ & $\begin{array}{l}\text { Y\&R BAV model } \\
\text { DataStream } \\
\text { CRSP } \\
\text { COMPUSTAT }\end{array}$ & $\begin{array}{l}\text { Aaker [1] } \\
\text { Mizik and Jacobson [30] } \\
\text { Pahud de Mortanges } \\
\quad \text { and Van Riel [33] }\end{array}$ & $\begin{array}{l}\text { Brand differentiation is the ability of the brand to stand } \\
\text { apart from its competitors. } \\
\text { Brand relevance is the personal relevance and } \\
\text { appropriateness and perceived importance of the brand. } \\
\text { Brand energy is the ability of a brand to meet customers' } \\
\text { needs and adapt to changing tastes in the future. }\end{array}$ \\
\hline $\begin{array}{l}\text { Brand esteem } \\
\text { Brand knowledge }\end{array}$ & $\begin{array}{l}\text { Y\&R BAV model } \\
\text { Survey } \\
\text { CRSP } \\
\text { COMPUSTAT }\end{array}$ & $\begin{array}{l}\text { Baldauf, Cravens, } \\
\quad \text { and Binder [10] } \\
\text { Mizik and Jacobson [30] } \\
\text { Pahud de Mortanges } \\
\quad \text { and Van Riel [33] }\end{array}$ & $\begin{array}{l}\text { Brand esteem is the extent to which consumers like a brand } \\
\text { and hold it in high regard. } \\
\text { Brand knowledge is the awareness and consumers' } \\
\text { understanding of the brand identity. }\end{array}$ \\
\hline Awareness & $\begin{array}{l}\text { Kantar Worldpanel } \\
\text { Y\&R BAV model } \\
\text { Survey data } \\
\text { CRSP } \\
\text { COMPUSTAT }\end{array}$ & $\begin{array}{l}\text { Srinivasan et al. [38]; } \\
\quad \text { Hanssens et al. [19] } \\
\text { Mizik and Jacobson [30] }\end{array}$ & $\begin{array}{l}\text { Awareness is the network of cognitive linkages that } \\
\text { consumers hold in their memory regarding the brand [21]. }\end{array}$ \\
\hline Consideration & $\begin{array}{l}\text { Kantar Worldpanel } \\
\text { Survey Data }\end{array}$ & $\begin{array}{l}\text { Srinivasan et al. [38]; } \\
\quad \text { Hanssens et al. [19] } \\
\text { Mizik and Jacobson [30] }\end{array}$ & $\begin{array}{l}\text { Consideration-the brands a customer considers when } \\
\text { making a purchase, is a precursor to greater sales. }\end{array}$ \\
\hline Liking & $\begin{array}{l}\text { Kantar Worldpanel } \\
\text { Y\&R BAV model } \\
\text { Survey } \\
\text { CRSP } \\
\text { COMPUSTAT }\end{array}$ & $\begin{array}{l}\text { Baldauf et al. [10] } \\
\text { Hanssens et al. [19] } \\
\text { Mizik and Jacobson [30] } \\
\text { Pahud de Mortanges } \\
\quad \text { and Van Riel [33] }\end{array}$ & $\begin{array}{l}\text { Brand liking is the extent to which consumers like a brand } \\
\text { and hold it in high regard. }\end{array}$ \\
\hline Brand attitude & $\begin{array}{l}\text { Techtel Corporation } \\
\text { Landor Image Power Survey } \\
\text { Y\&R BAV model }\end{array}$ & $\begin{array}{l}\text { Aaker and Jacobson [3] } \\
\text { Lane and Jacobson [26] } \\
\text { Mizik and Jacobson [31] }\end{array}$ & Consumers' overall evaluations of a brand. \\
\hline Brand/customer loyalty & $\begin{array}{l}\text { Annual reports } \\
10-\mathrm{K} \text { statement } \\
10-\mathrm{Q} \text { statement }\end{array}$ & Gupta et al. [18] & $\begin{array}{l}\text { A deep held commitment to rebuy or repatronize a preferred } \\
\text { product/service consistently in the future, thereby causing } \\
\text { repetitive same-brand or same brand-set purchasing, } \\
\text { despite situational influences and marketing efforts having } \\
\text { the potential to cause switching behavior. }\end{array}$ \\
\hline Perceived quality & EquiTrend & $\begin{array}{l}\text { Aaker and Jacobson [2] } \\
\text { Baldauf et al. [10] }\end{array}$ & $\begin{array}{l}\text { Consumer's judgment about a brand's overall excellence } \\
\text { or superiority. }\end{array}$ \\
\hline $\begin{array}{l}\text { B. Market-based } \\
\text { brand equity }\end{array}$ & Sample data sources & Illustrative papers & Definition \\
\hline Brand price premium & J.D. Power & Ailawadi et al. [8] & Brand's unit price - benchmark brand's price \\
\hline Brand volume premium & $\begin{array}{l}\text { Dominick's database } \\
\text { IRI Marketing Fact book }\end{array}$ & This paper & Brand's unit volume - Benchmark brand's volume \\
\hline Brand revenue & Same as above & $\begin{array}{l}\text { Ailawadi et al. [8] } \\
\text { Pauwels et al. [35] } \\
\text { This paper }\end{array}$ & Brand's unit volume $\times$ brand's price \\
\hline Brand revenue premium & Same as above & $\begin{array}{l}\text { Ailawadi et al. [8] } \\
\text { This paper }\end{array}$ & $\begin{array}{l}\text { The difference in revenue between a branded good and a } \\
\text { private label good } \\
\text { (Brand's unit volume } \times \text { brand's price with after-market } \\
\text { accessories }(- \text { benchmark brand's unit volume } \times \\
\text { benchmark brand's price with after-market accessories) }\end{array}$ \\
\hline Brand accessory revenue & Same as above & $\begin{array}{l}\text { Accessory revenue } \\
\text { Introduced in this paper }\end{array}$ & $\begin{array}{l}\text { Brand's unit volume } \times \text { (brand's price with after-market } \\
\text { accessories-brand's price with factory-installed optional } \\
\text { accessories) }\end{array}$ \\
\hline $\begin{array}{l}\text { C. Finance-based brand } \\
\text { equity }\end{array}$ & Data sources & Illustrative papers & Definition \\
\hline Intangible asset & $\begin{array}{l}\text { CRSP } \\
\text { COMPUSTAT } \\
\text { National Bureau of } \\
\quad \text { Economic Research (NBER) }\end{array}$ & $\begin{array}{l}\text { Simon and Sullivan [37] } \\
\text { Barth et al. [11] }\end{array}$ & $\begin{array}{l}\text { Residual market value after other tangible sources of firm } \\
\text { value are accounted for. }\end{array}$ \\
\hline
\end{tabular}


Table 1 (continued)

\begin{tabular}{llll}
\hline Brand value & Interbrand & Kerin and & Branded earnings, which are based on the brand strength, \\
& Press releases and articles & Sethuraman [24] & Madden et al. [27] \\
Dow & Mitchell [29] & arrive at a brand value. \\
Jones Interactive database & Govindaraj et al. [17] & \\
& & \\
\hline
\end{tabular}

A third approach to measuring brand equity is based on financial market performance [9] wherein brand equity is estimated from the residual in the model of the value of a firm's assets [37]. Such approaches typically decompose firm value into tangible assets such as plant and equipment or net receivables, and intangible components reflecting goodwill and brand investments and other forms of intellectual property. Increasingly, researchers have used a composite of customer-based and market-based brand equity metrics to derive estimates of finance-based brand equity. An example of this "price-earnings multiple" approach is Interbrand's brand equity valuation [24], which considers branded earnings (i.e., economic profits attributable to brand) times brand strength (as an indication of the discount rate for future brand revenue streams), thus combining the subjective consumer mindset of brand equity with objective brand performance in the product market. While financial market outcomes are based on future potential [8] and hence are subjective, product market outcomes such as the proposed accessory premium metric reflect the current strength of the brand and may serve as useful leading indicators of future brand health.

\section{Data}

We focus on automobiles and the add-on options that are purchased from the dealer, i.e., retailer installed optional accessories. We use sales transaction data for California from J.D. Power \& Associates and treat "options" built into the car by the manufacturer as part of the car/brand. ${ }^{2}$ California is the largest regional market in the US, representing approximately $16 \%$ of sales and is considered representative of the overall US market [36]. Focusing on a single area helps control for possible regional differences in brand strength [13]. We use

\footnotetext{
${ }^{2}$ In many cases, it is difficult to distinguish optional accessories from the car itself if, for example, many models come with leather trims or automatic transmissions. What is an optional accessory for one car can be a standard feature for another. Our analysis uses a conservative measure of accessory purchases. Future work may attempt to separate manufacture options from the car itself.
}

data from a sample of 1,100 California dealerships containing every new car sales transaction from 1998 through 2000.

Each observation in the data contains the transaction date, customer information, manufacturer, model year, make, model, trim, and transaction price, along with after-market (retailer installed) optional accessories, and sales promotions operationalized as the monetary equivalent of all promotional incentives. These retailer installed optional accessories including auto security and alarm systems, mobile electronics, performance and styling accessories (e.g., seat upholstery, paint sealant, and window etching), custom wheels and tire packages, auto detailing, etc. Table 2 provides the definitions of the variables used in the analysis.

We first computed the total revenue premium at the brand level, following the method of Ailawadi, Lehmann, and Neslin [8].

The brand revenue premium is generally in line with market share, i.e., the high-share brands, Accord and Camry, command higher brand revenue premiums compared to the low-share brands. Additionally, as Table 3 shows, the brand revenue premiums are stable from year to year.

We concentrate on the sedan category, which had eight major brand nameplates from 1998 to 2000-Honda Accord, Toyota Camry, Ford Taurus, Nissan Maxima, Dodge Intrepid, Volkswagen Passat, Chevrolet Impala, and Chevrolet Lumina. An advantage of focusing solely on the sedan category is that features that are considered as standard in the base model are similar across brands within the category enabling comparisons of the extra add-on retailer (dealer)-installed optional accessory sales across manufacturers. The aggregate California market shares over the 3 years were Accord (50.1\%), Camry (26.4\%), Taurus (4.5\%), Maxima (8.7\%), Intrepid (3.3\%), Passat (3.7\%), and Impala (2.7\%). Perhaps unsurprisingly, the performance of these brands shows considerable stability from year to year.

\section{Results: Dealer Installed Accessory Sales}

\subsection{Basic Results}

Automobiles have no generic or store brand equivalent. Therefore, to calculate the revenue premium, we chose the 
Table 2 Variable definitions

\begin{tabular}{|c|c|}
\hline Variable & Definition \\
\hline Volume & Number of automobiles of the brand sold \\
\hline Price premium & $\begin{array}{l}\text { Brand's price with after-market accessories - benchmark brand's } \\
\text { price with after-market accessories }\end{array}$ \\
\hline Volume premium & Brand's unit volume - benchmark brand's volume \\
\hline Brand revenue & Brand's unit volume $\times$ brand's price with after-market accessories \\
\hline Revenue premium & $\begin{array}{l}\text { (Brand's unit volume } \times \text { brand's price with after-market accessories }- \\
\text { benchmark brand's unit volume } \times \text { benchmark brand's price with } \\
\text { after-market accessories) }\end{array}$ \\
\hline Accessory revenue & $\begin{array}{l}\text { Brand's unit volume } \times \text { (brand's price with after-market accessories }- \\
\text { brand's price with factory-installed optional accessories included) }\end{array}$ \\
\hline
\end{tabular}

Dodge Intrepid as the benchmark brand since it has the lowest share (e.g., [8]) among the brands that were available throughout the entire time period analyzed. We did not use the two smaller share brands, Chevrolet Impala and Chevrolet Lumina, as benchmarks since they were not available throughout the time period. The Impala was resurrected in the 2000 model year to replace the discontinued Lumina.

\subsection{Accessory Revenue}

As mentioned earlier, one important aspect of brand equity is its facilitation of up-selling or cross-selling additional items (accessories). Indeed, it is possible that a major aspect of brand equity is the additional sales of optional accessories it generates in addition to the base item. Table 3 presents the brand accessory revenues. Add-on accessory revenue represents a substantial fraction of the value of a brand to a dealer. It is interesting to note that the three Japanese manufacturers, Honda Accord, Toyota Camry, and Nissan Maxima, are the top three ranked brands as far as this metric of brand equity is concerned. It is also interesting to note that, although sales of Maxima and Taurus are similar, Maxima had much higher revenue premiums and accessory revenues, suggesting it was the healthier of the two brands.

An examination of the trends in the brand accessory premiums and percentage accessory premiums shows that these are stable from year to year. The increase in premiums from 1998 to 2000 for Honda, Nissan, and Toyota and the decline for Chevrolet's Lumina and Chevrolet Impala over the same time frame are reflective of the overall market share trends in the US.

\subsection{Relation Between Accessory Sales and Brand Revenue Premiums}

Table 4 summarizes the cross-sectional correlation of the brand accessory revenue premium with other measures. There are several notable results. First, accessory revenue correlates strongly with both the volume premium (0.98) and the brand

Table 3 Sales, revenues, brand revenue premium and accessory premiums

\begin{tabular}{|c|c|c|c|c|c|c|c|c|}
\hline & Accord & Camry & Taurus & Maxima & Intrepid & Passat & Impala & Lumina \\
\hline \multicolumn{9}{|l|}{1998} \\
\hline Unit sales & 11,760 & 7,040 & 1,020 & 1,260 & 830 & 520 & 0 & 330 \\
\hline Brand revenues (in \$ millions) & 246.5 & 146.3 & 20.2 & 31.6 & 18.8 & 12.6 & 0 & 6.6 \\
\hline Brand revenue premium (in $\$$ millions) & 227.7 & 127.5 & 1.4 & 12.8 & 0 & $(6.2)$ & $(18.8)$ & $(12.2)$ \\
\hline Accessory revenue (in $\$ 000 \mathrm{~s}$ ) & 4,360 & 3,920 & 310 & 570 & 390 & 140 & 0 & 70 \\
\hline \multicolumn{9}{|l|}{1999} \\
\hline Unit sales & 12,810 & 6,950 & 1,070 & 2,470 & 870 & 930 & 650 & 220 \\
\hline Brand revenues (in \$ millions) & 269 & 143.3 & 20.7 & 61.7 & 19.9 & 22.9 & 14.5 & 4.5 \\
\hline Brand revenue premium (in $\$$ millions) & 249.1 & 123.4 & 0.8 & 41.8 & 0 & 3 & $(5.4)$ & $(15.4)$ \\
\hline Accessory revenue (in $\$ 000 \mathrm{~s}$ ) & 4,440 & 3,390 & 310 & 980 & 460 & 210 & 170 & 60 \\
\hline \multicolumn{9}{|l|}{2000} \\
\hline Unit sales & 12,620 & 6,200 & 1,240 & 2,110 & 770 & 1,070 & 890 & 20 \\
\hline Brand revenues (in \$ millions) & 268.3 & 131.9 & 25.3 & 55.1 & 18.4 & 28.6 & 20.4 & 0.3 \\
\hline Brand revenue premium (in $\$$ millions) & 249.9 & 113.5 & 6.9 & 36.7 & 0 & 10.2 & 2 & $(18.1)$ \\
\hline Accessory revenue (in $\$ 000 \mathrm{~s}$ ) & 5,130 & 2,730 & 340 & 760 & 440 & 200 & 200 & 0 \\
\hline
\end{tabular}


Table 4 Accessory premium-cross-sectional correlations

\begin{tabular}{lcc}
\hline & Accessory revenue & Brand revenue premium \\
\hline Accessory revenue & 1.000 & 0.979 \\
Volume premium & 0.981 & 0.999 \\
Price premium & -0.164 & -0.124 \\
Brand revenue premium & 0.979 & 1.000 \\
\hline
\end{tabular}

revenue premium (0.98). However, the correlation with the price premium is low $(-0.16)$. Table 5 summarizes the crosssectional correlation of the brand accessory revenue premium with other measures for each of the years from 1998 to 2000. The results are robust to aggregation issues. Overall, the correlations suggest that accessory revenue is a good indicator of brand equity. In this category, interestingly, brand equity primarily comes from volume premiums that are obtained by means of lower price premiums.

Overall, add-on accessory sales correlate strongly with the brand revenue premium metric [8]. Note that, as pointed out earlier, for durable goods, accessory sales may be easier to compute since they do not depend on the choice of a generic or branded equivalent product and hence may be a useful indicator of brand equity. ${ }^{3}$

The correlations of the brand revenue premium with the add-on accessory sales are high on a year-by-year basis as well. Specifically, accessory sales correlate strongly with the brand revenue premium $(0.88,0.91$, and 0.96 in years 1998 , 1999, and 2000, respectively).

\section{Using Revenue Premium Measures Diagnostically}

While it is useful to assess a brand's equity, for managers, it may be more important to utilize it as a diagnostic tool. One way to use the revenue or accessory premium measure of brand equity is as leading indicators and to track it over time and study changes in it. An alternative approach is to examine the revenue premium across segments to aid in targeting and effort allocation. Here, we demonstrate a third use to forecast future brand health based on age cohort analysis. While other demographics (e.g., education) may be potentially useful to examine the revenue premium variation across segments (if present), the age-cohort analysis helps in identifying leading indicators since it serves as a proxy for longitudinal analysis and hence is most useful as a forward-looking diagnostic tool.

\footnotetext{
${ }^{3}$ The independence of the proposed brand equity from the choice of the benchmark makes it easier to compute and potentially more useful than other variants of this metric such as the ratio of the accessory premium to brand revenue premium.
}

Table 5 Accessory premium-cross-sectional correlations by year

\begin{tabular}{lrc}
\hline & Accessory revenue & $\begin{array}{c}\text { Brand revenue } \\
\text { premium }\end{array}$ \\
\hline 1998 & 1.000 & \\
$\quad$ Accessory revenue & 0.972 & 0.971 \\
Volume premium & -0.322 & 0.999 \\
Price premium & 0.971 & -0.300 \\
Brand revenue premium & & 1.000 \\
1999 & 1.000 & \\
Accessory revenue & 0.980 & 0.977 \\
Volume premium & -0.264 & 0.999 \\
Price premium & 0.977 & -0.211 \\
Brand revenue premium & & 1.000 \\
2000 & 1.000 & \\
Accessory revenue & 0.997 & 0.994 \\
Volume premium & -0.038 & 0.999 \\
Price premium & 0.994 & 0.019 \\
Brand revenue premium & & 1.000 \\
\hline
\end{tabular}

Figure 1 profiles brand sales by age cohort while Fig. 2 profiles brand revenue premium by age cohort. Examining sales by age cohort shows that sales of four brands (Accord, Camry, Maxima, and Passat) peaks in the 40-50 age category (Fig. 1), while sales of Taurus and Impala peak in the 50-60 age group. Thus this provides little insight into the relative
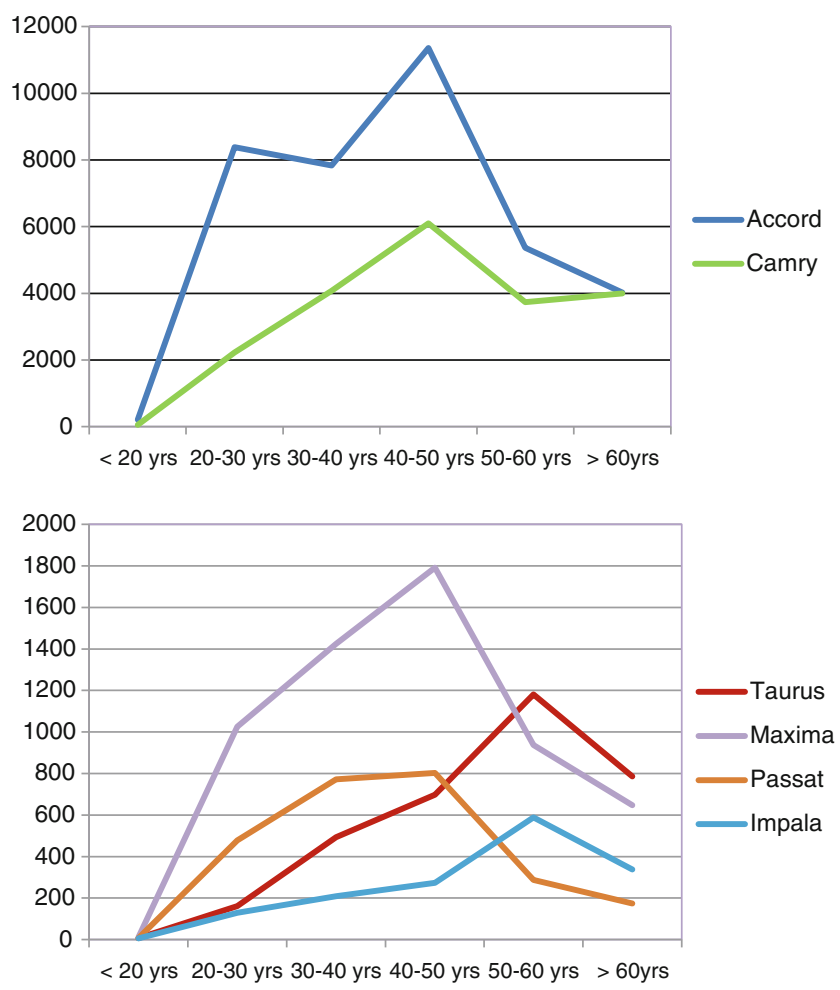

Fig. 1 Brand sales by age cohort 


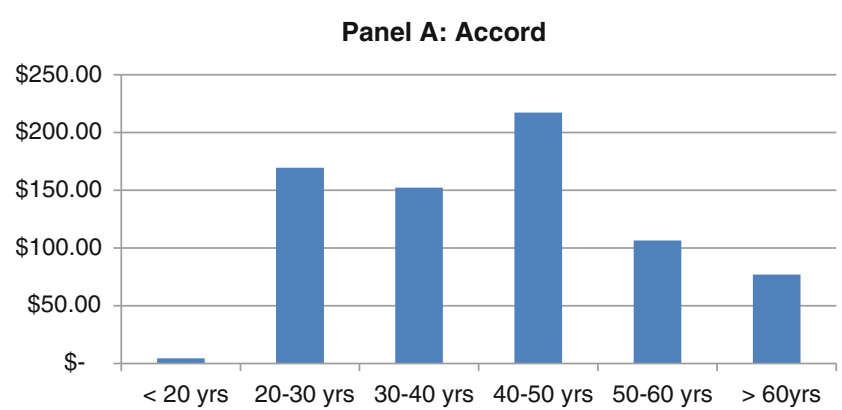

Panel B: Camry

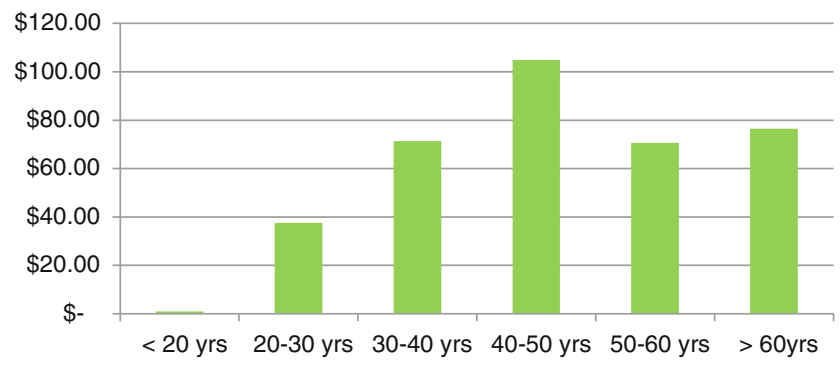

Panel C: Nissan

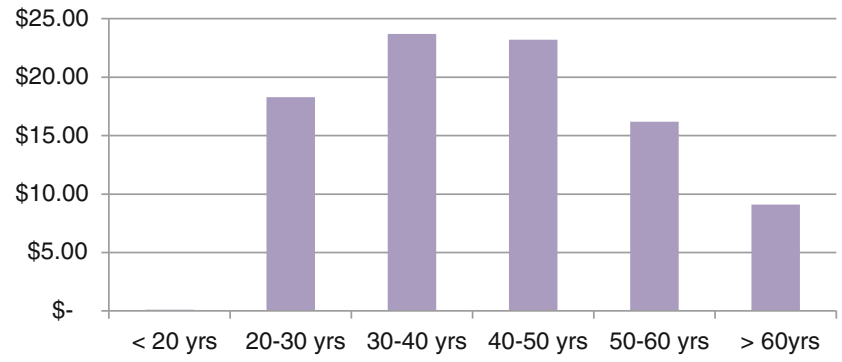

Fig. 2 Brand revenue premium (in millions) by age cohort

health (strength) of the brands, other than that Taurus and Impala are aging brands.

To gain additional insight, we examine how brand equity varies by age cohort [28]. For products such as cars, there is relatively uniform usage across age cohorts (in contrast to toys or medicinal products for senior citizens which vary widely in use across age cohorts), and therefore when the bulk of the equity comes from younger cohorts, the future is, ceteris paribus, good. On the other hand, when equity comes from older cohorts, the brand is at risk of becoming irrelevant. To demonstrate this, we computed the aggregate (brand plus accessory) revenue premium for six brands from 1998 to 2000. We combined the revenue premiums and accessory sales measures given their high correlation as well as the fact that they logically both assess the brand equity construct. As Fig. 2 shows, in 2000, Accord, Camry, and Maxima had a large brand premium and strength in all age cohorts which portended a healthy next decade. By contrast, Taurus only had

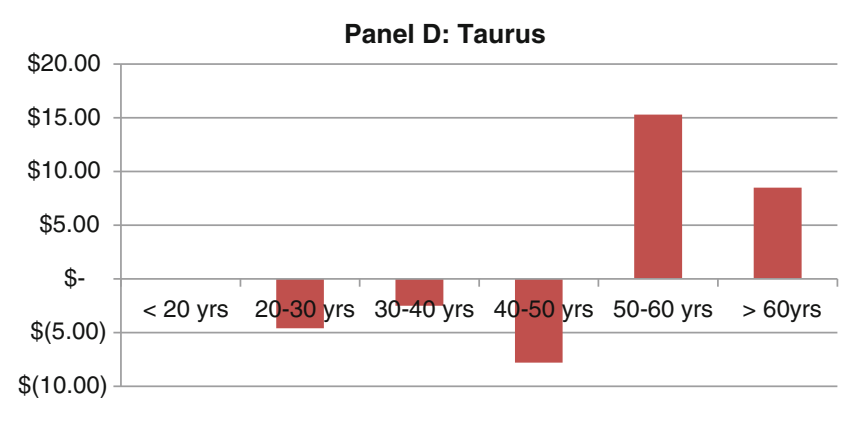

Panel E: Passat

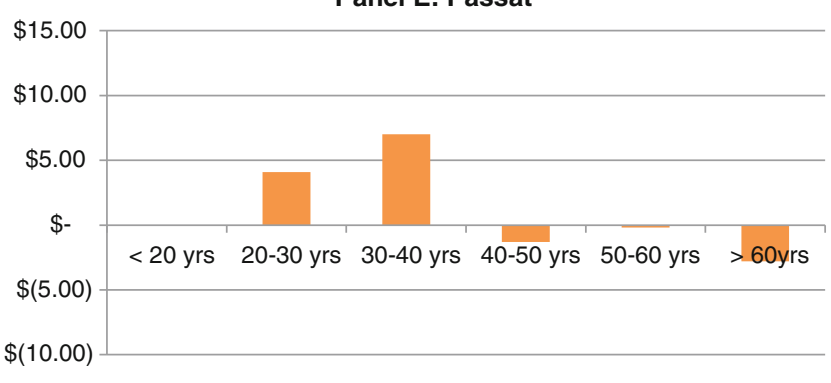

Panel F: Impala

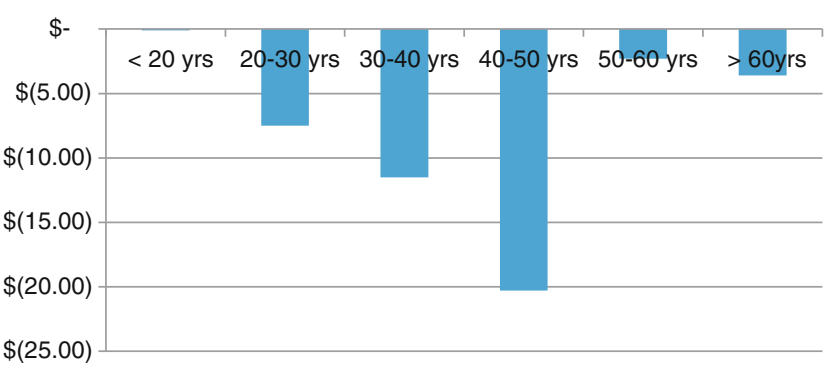

positive equity for those 50 and older. Even worse off was Impala, which had negative equity in all age groups. This unhealthy situation led Ford to drop Taurus, although Ford subsequently reintroduced it. The Passat, in contrast, had a positive equity in all except the 60 and over age segments. This suggests that Passat is relatively well positioned for the future. Unsurprisingly, given this analysis, Accord and Camry became the top selling models in the ensuing decade while Impala and Taurus performed poorly. More broadly, these results suggest that examining brand revenue premium measures at the segment level, here based on age, may provide a useful forward looking metric for examining brand health.

\section{Implications and Conclusion}

This paper has extended the revenue premium measure of brand equity and produced two main findings based on the 
automobile market. First, higher add-on (accessory) sales accrue to higher equity brands which makes accessory sales a potentially useful measure of brand equity. Second, observing the revenue premium measure of brand equity at the agebased segment level appears to provide a useful leading indicator of future brand health.

For manufacturers of high-equity durable goods brands, the ability of retailers to sell more accessories makes the brand more attractive to the retailers and hence aids in gaining both distribution channel coverage and support. For consumers of high-equity brands, there is a tendency to cross-buy accessories (or in the case of a car, to "trick it out"), both at the time of the initial purchase as well as in the future. Having a "loaded" car also may result in enhanced customer retention. Taken as a whole, then, our results provide evidence of a "triple jeopardy" effect of high-equity durable goods brands. From the point of view of the manufacturers, retailers, and consumers, high-equity brands benefit from the opportunity to sell addons that improve manufacturer and retailer profitability, and in turn, enhances customer retention.

\section{Future Research}

Our results point to several areas for further work as follows:

- Research is needed to see how well these results hold outside the particular category (automobile sedans) studied here.

- Behavioral and survey work, including controlled experiments and conjoint analysis studies can be helpful in understanding the cognitive and emotional processes that lead to accessory purchases.

- The value of accessories added by manufacturers is potentially a useful metric of brand equity so the relative importance of dealer-installed versus manufacturerinstalled optional accessories in contributing to brand equity is a topic for future research.

- Other aspects of "after-market" sales could also be productively examined such as service contracts and warranties as reflexive measures of brand equity.

The results also suggest several other directions for future research and research questions. For example, how can you disentangle the effect of brand equity on accessory purchases from the tendency of people who like high-end products to value accessories more highly (i.e., a selection effect)? Related to this, higher brand equity items tend to be higher in price. This makes the price of accessories a smaller percentage of the base price and hence easier to justify.

Another fruitful area relates to which accessories are bought. One would expect buyers of less well-known brands and generics to be more concerned with operational risk and hence to buy accessories like extended warranties. By contrast, buyers of high-end brands are typically less concerned with quality and hence may allocate their accessory spending to more hedonic accessories.

Having a product with accessories is likely to lead consumers to be more attached to it, i.e., have greater possession utility, as long as the accessories are functional. What happens when they stop functioning is unclear. Similarly, how the presence of accessories impacts their usage is worth investigating.

Finally, and more broadly, is the generic issue of why people buy accessories, especially in cases where they end up not using them. Several reasons beyond brand equity and simple preference for them exist, including self-presentation, a desire to have them "just in case," the hope it increases resale value, the simple desire to "tinker" with them, and the desire to accommodate the needs of multiple users in an equitable way (i.e., having something for everyone in it).

Overall, building strong brands and measuring their value has become a priority for many organizations. Our findings demonstrate that, at least for durable goods, one way in which brand equity is manifested is through an "accessory premium." Hopefully, the results presented here will encourage work to further explore its value both as a measure of brand equity and a metric worth monitoring and managing.

\section{References}

1. Aaker DA (2003) The power of the branded differentiator. MIT Sloan Manag Rev 45(1):83-87

2. Aaker DA, Jacobson R (1994) The financial information content of perceived quality. J Marketing Res 31(2):191-201

3. Aaker DA, Jacobson R (2001) The value relevance of brand attitude in high-technology markets. J Marketing Res 38(November):485493

4. Aaker DA, Keller KL (1990) Consumer evaluations of brand extensions. J Marketing 54:27-41

5. Aaker JL, Fournier SM, Brasel SA (2004) When good brand do bad. J Consumer Res 31:1-16

6. Agarwal MK, Rao VR (1996) An empirical comparison of consumer-based measures of brand equity. Marketing Lett 7(3): $237-47$

7. Agres SJ, Dubitsky TM (1996) Changing needs for brands. J Advertising Res 36(1):21-30

8. Ailawadi KL, Lehmann DR, Neslin SA (2003) Revenue premium as an outcome measure of brand equity. J Marketing 67:1-17

9. Amir E, Lev B (1996) Value-relevance of nonfinancial information: the wireless communications industry. J Accounting Econ 22(1-3):3-30

10. Baldauf A, Cravens KS, Binder G (2003) Performance consequences of brand equity management: evidence from organizations in the value chain. J Product Brand Manag 12(4/5):220-34

11. Barth ME, Clement MB, Foster G, Kasznik R (1998) Brand values and capital market valuation. R Accounting Stud 3(1/2):41-68

12. Boulding W, Lee E, Staelin R (1994) Mastering the mix: do advertising, promotion, and sales force activities lead to differentiation? J Marketing Res 31(2):159-72 
13. Bronnenberg BJ, Dhar SK, Dubé J-P (2007) Consumer packaged goods in the united states: national brands, local branding. $\mathrm{J}$ Marketing Res 64:4-13

14. Business week. 2007. Using accessories to upsell. (June 27, 2007). Accessed April 1 2011. [http://www.businessweek.com/smallbiz/ content/jun2007/sb20070627_569179.htm]

15. Dhar R, Simonson I (1992) The effect of the focus of comparison on consumer preferences. J Marketing Res 29:430-440

16. Dubin JA (1998) The demand for branded and unbranded products: an econometric method for valuing intangible assets on studies in consumer demand: econometric methods applied to market data. Kluwer Academic Publications, Norwell, MA, pp $77-127$

17. Govindaraj S, Jaggi B, Lin B (2004) Market overreaction to product recall revisited - the case of firestone tires and the ford explorer. Rev Quant Fin Accounting 23(1):31-54

18. Gupta S, Lehmann DR, Stuart JA (2004) Valuing customers. J Marketing Res 41:7-18

19. Hanssens DM, Pauwels KH, Srinivasan S, Vanhuele M, Yildirim G (2013) Consumer attitude metrics for guiding marketing mix decisions. Working paper, UCLA Anderson School of Management

20. Hoeffler S, Keller KL (2003) The marketing advantages of strong brands. J Brand Management 10(6):421-445

21. Keller KL (1993) Conceptualizing, measuring, and managing customer-based brand equity. J Marketing 57(1):1-22

22. Keller KL, Lehmann DR (2003) The brand value chain: Optimizing strategic and financial brand performance. Marketing Management (May/June) 26-31

23. Keller KL, Lehmann DR (2006) Brands and branding: research findings and future priorities. Marketing Sci 25:740759

24. Kerin R, Sethuraman R (1998) Exploring the brand valueshareholder value nexus for consumer goods companies. J Acad Marketing Sci 26(4):260-73
25. Lal R, Narasimhan C (1996) The inverse relationship between manufacturer and retailer margins: a theory. Marketing Sci 39:408-420

26. Lane V, Jacobson R (1995) Stock market reactions to brand extension announcements: the effects of brand attitude and familiarity. J Marketing 63(Special Issue):180-97

27. Madden JT, Fehle F, Fournier S (2006) Brands matter: an empirical demonstration of the creation of shareholder value through branding. J Acad Marketing Sci 34(2):224-35

28. McCann D, Reibstein D (1985) Forecasting the impact of socioeconomic and demographic change on product demand. J Marketing Res 22:415-423

29. Mitchell ML (1989) The impact of external parities on brand-name capital: the 1982 tylenol poisonings and subsequent cases. Econ Inq 27(4):601-618

30. Mizik N, Jacobson R (2008) The financial value impact of perceptual brand attributes. J Marketing Res 45(1):15-32

31. Mizik N, Jacobson R (2009) Valuing branded businesses. J Marketing 73(6):137-53

32. Muthukrishnan AV (1995) Decision ambiguity and incumbent brand advantage. J Consumer Res 22(June):98-109

33. Pahud De Mortanges C, Van Riel A (2003) Brand equity and shareholder value. Euro Manag J 21(4):521-27

34. Park CS, Milberg S, Lawson R (1991) Evaluation of brand extensions: the role of product feature similarity and brand concept consistency. J Consumer Res 18(September):185-193

35. Pauwels K, Silva-Risso J, Srinivasan S, Hanssens DM (2004) New products, sales promotions, and firm value: the case of the automobile industry. J Marketing 68(4):142-56

36. Scott-Morton F, Zettelmeyer F, Silva-Risso J (2001) Internet car retailing. J Industrial Econ XLIX(4):501-519

37. Simon CJ, Sullivan MW (1993) The measurement and determinants of brand equity: a financial approach. Marketing Sci 12(1):28-52

38. Srinivasan S, Vanhuele M, Pauwels K (2010) Mind-set metrics in market response models: an integrative approach. J Marketing Res 47(4):672-84 